\title{
觧脉石を伴った煩部血管㬐の１例
}

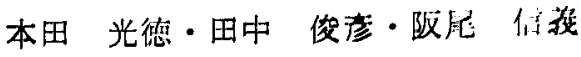 \\ 須川亮
}

\section{A case of hemangioma of the left cheek with phlebolithiasis.}

\author{
Mitsunori Honda - Tosihiko Tanaka - Nobuyosi Sakao \\ Akira Sugawa
}

\section{I 楮 䡒}

觧脉石を伴ら顔面および口腔内に発現をみた血管腪は， 最近報告がつぎつぎになされている(12)(4)8/6)738)10．

私共も静脉石を伴った血管隀の症例に遭遇し，摘出を 行なったのでその概要について報告する.

\section{II 症例 \\ 患者：如性 19 才 会社員 \\ 初診: 昭和 45 年 7 月 日 \\ 主訴：左側口腔内頓部の腫脹および内出血. \\ 家族歴および既往歴：特記すべき事項なし。}

現病歴：約 6 カ月前写真层影したところ，左煩部の瘟 脹に気付いたが放固、6月頃より右眉凝りを訴え，内科 医受診, 左口腔内の腫脹を指摘され，さらに腫脤部の試 験穿刺をされた，以啳時々内出血があるため当科外来へ 紹介された。

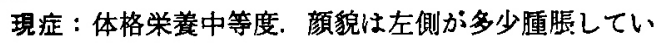
る感を思わせる程度で，同部皮庙の色調に变化なく，そ の他異常はない.

口腔内所見：畨牙触蝕，齿列不正はなく，右側下額第

1 大田歯に金属冠があるのみである.

左煩部の耳下腺開口部下部に5づら即大の嬄隆を認め, 触診による硬度は弾力性軟で，王痛はないが，尰㢞の下 部に多少暗紫色の着色がみられる以外に著变なく，また 炎症所見は認められない. 所属リンパ節のE痛腫脹むな い(写真 1).

臨床診断：煩部血管腫

処置および䅅過：7月日，局麻の下に尰瘤のやゃ 上縁に約 $4 \mathrm{~cm}$ の横切開を加え，煩粘膜を除々に鈍的に 剥離し，露出した尰瘤中に蛇行した暗赤色の血管がみら

大阪学災病院口腔外科（主任：本田光德）

Department of Oral Surgery, Osaka Rosai Hospital (Chief : Dr. Mitsunori Honda)

受付 昭和 46 年 11 月 8 日
れたので，婳瘦の速心および近心部にて結柴を行ない,

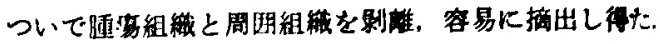
術後3 日間は開口不能約 $1.5 \mathrm{~cm}$ ですったか，徐々下 回復し，㓣部の出血あなく，6日目で全拔稀を行なった その後程過良好で現在まで罢常を訴えていない(写共2).

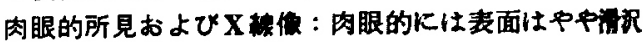

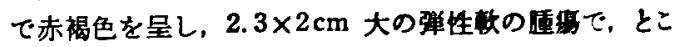
ろところに硬様粟粒大のるのを証めたので，X楾撮影を

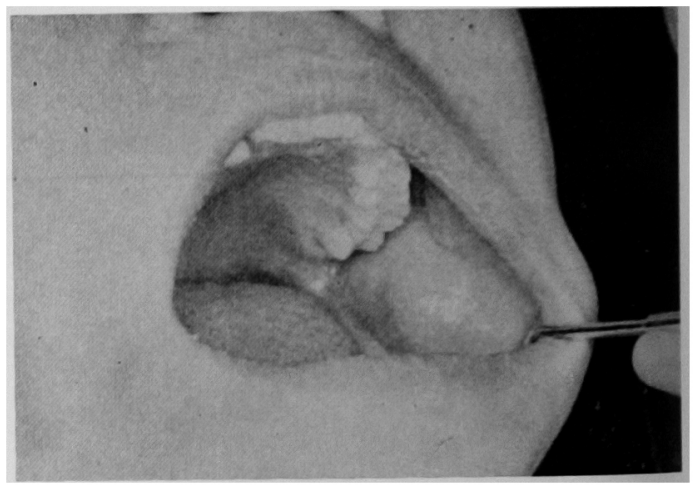

军真 1

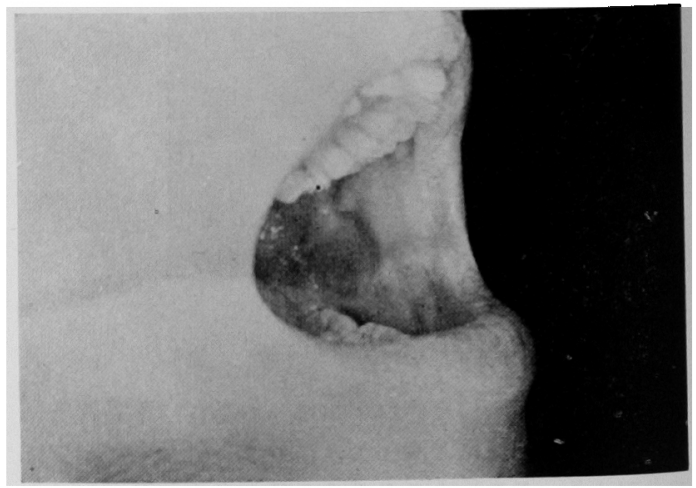

写真 2 


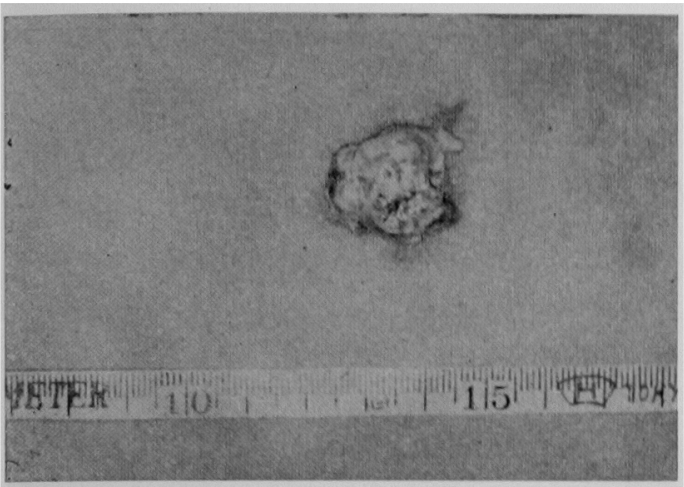

军竞 3

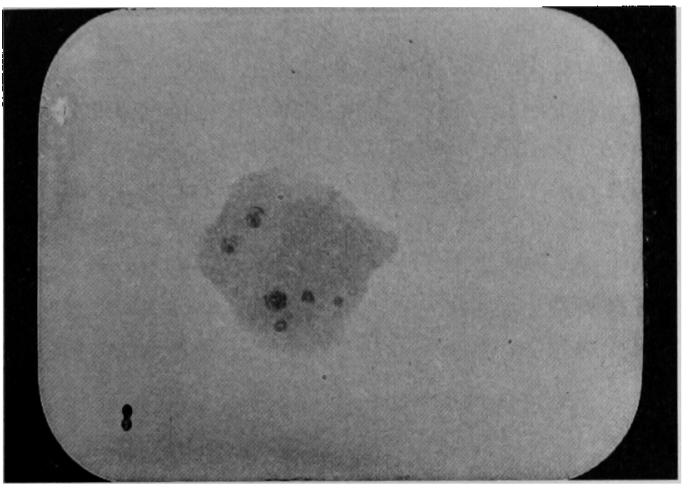

写 $\mathrm{x} 4$

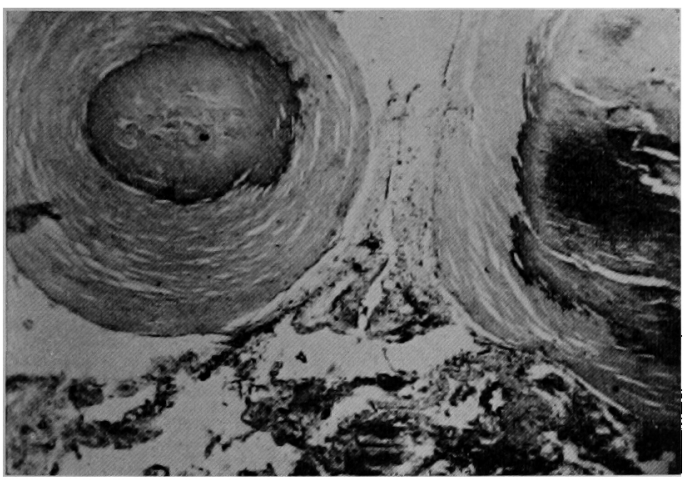

写交 5

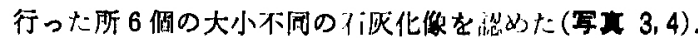

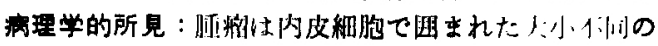

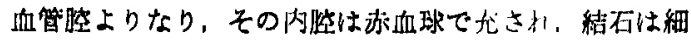

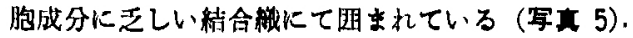

\section{III 考 需}

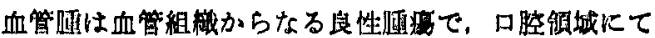
は口唇，舌，煩粘膜に好発するか，血管呮の中に結石形

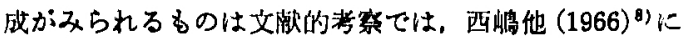

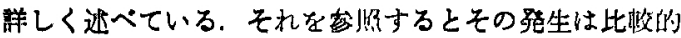

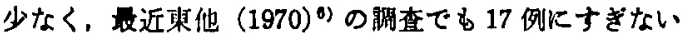
といっている.

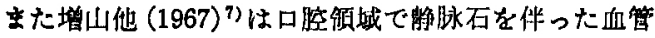
厘と，結石を認めなかったるのとの比较を詳速している が，それによると昭和 39 年より昭和 41 年の 3 年間で， 血管連のみの症例は 62 例，結石を有したものは 7 例と の報告中， 5 例は煩粘膜であった。

な打結石の発生機転には局所成因説と全身的成因説と があるが，そのいづれかる不明である。

\section{IV むす び}

私共は 19 才の女性にみられた静脉結石を有する煩部 血管腫の 1 例に䢙遇し，その処䈯および程過について報 告した.

（本論文の要旨は第 16 回口胫外科学全総会にて報告した） 文

献

1) Parker, L. A. : Phleboliths. OS OM \& OP 18:476 1964.

2) Smith, F.J. : Massiveoral hemangioma with phlebolithiasis. OS OM \& OP $21: 831966$.

3) Thoma, K.H. and Goldman, H.M. (1960): Oral Pathology ed. 4 Mosby Co, St Louis 1931-1937.

4) 浜田他：髅脉石を伴 5 血管茞のI症例. 口外誌 $14: 85$ 1968.

5）久野他：静脈石を有した口腔底部血管腯の 1 例. 口外詰 $15: 1161969$

6) 東他：㬹㟲石を有した舌下血管腫の 1 例とその㬹眽石の Electron Microprobe X-ray Analyzer による分析所見 について. 口外誌 $16: 1811970$.

7）増山他：口腔領域で觧脉石を伴った血管嚙の症例につい て. 阪大歯学誌 $12: 2791967$.

8）西嵦他：結石を有する煩部血管嗹の1例ならびに文献的 考察. 口外䛠 $12: 1711966$.

9）尾筑他：稀有なる静脈石を伴亏顏面血管腫の 2 例に就い て. 阪大藏学誌 4:1269 1959.

10）柘植他：多数の静脉石を伴った頼部血管腫の 1 例. 口科詰 $16: 3981967$. 